\title{
16
}

\section{Independents Return and the 'Almost' Hung Parliament}

\author{
Jennifer Curtin
}

One wonders if, when Malcolm Turnbull called the federal election early, the chance of another hung parliament crossed his mind. In 2010, a first-term government, whose electoral position had seemed unassailable six months earlier, was almost defeated and with it came the first 'hung' parliament since 1940. It was interpreted as an exceptional moment in Australia's political history (Costar 2012).

However, by the end of May 2016, the proposition of a hung parliament was back in the mix and the likely (re)election of several Independents to the House of Representatives increased in significance. On 6 June, the Australian's Newspoll indicated that 15 per cent of respondents were considering voting for an Independent or micro party, the highest level of support (during a formal election campaign) in the poll's 31-year history (Hudson 2016). An Ipsos (2016) poll 10 days later also suggested the vote for 'Others' stood at almost half that of Labor's support. Although seat-specific polls were particularly unreliable (see Jackman and Mansillo, Chapter 6 , this volume), that the national polls were showing a combined vote of 28 per cent support for Greens, micro parties and Independents was sufficiently perturbing to prompt both Turnbull and Barnaby Joyce to urge voters to avoid the 'chaos of a hung parliament' (Davey 2016). 
In the end, these calls fell on deaf ears. The combined vote for minor and micro parties as well as Independents remained sufficiently high to result in the narrowest possible victory for the Coalition. Although it was to be the minor parties rather than the Independents that scooped a significant share of the non-major party vote, Independents remained keenly visible during the campaign and in the results. There were 108 candidates who stood as Independents, and collectively they won 2.81 per cent of the primary vote nationally compared to 1.85 per cent for the Nick Xenophon Team (see Kefford, Chapter 15, this volume). Moreover, while in 2010 it was evident early in the count that neither Labor nor the Coalition would win the 76 seats required, resulting in 17 days of negotiations to form a government, in 2016 it was less clear cut whether the Coalition would need the Independents or micro parties to govern.

It was to be 17 days after the 2 July election that Turnbull was sworn in as prime minister. No protracted deals were required but neither were they desired by the Independents. Andrew Wilkie and Cathy McGowan agreed to support the government in terms of supply and confidence, but chose to go no further. Rather, they explicitly stated that being an Independent meant standing by principles rather than exchanging them for something — thus retaining independence meant 'no deals' (Hutchens 2016; Kimmorley 2016).

Arguments as to whether this support for Independents represented an ongoing malaise, a fragmentation of the party system or some other kind of protest vote have been canvassed in many elections before, both in Australia and elsewhere (Curtin 2004). In 1998, the backlash against John Howard's government almost cost him office, in part a result of the swing towards then 'Independent' Pauline Hanson and her fledgling One Nation party. However, her style of independent politics was in stark contrast to that of Peter Andren, MP for Calare from 1996 to 2007 and champion of regional policy issues as well as democratic accountability and human rights (Costar and Curtin 2004). Between then and now, we have witnessed the rise of other successful Independents: Bob Katter (now leader of a minor party, see Kefford, Chapter 15, this volume), Tony Windsor and Rob Oakeshott, followed by Wilkie in 2010 and McGowan in 2013. ${ }^{1}$ While Wilkie

1 While the Australian counts Katter as one of the parliament's Independents (Black 2016), the Australian Electoral Commission (AEC) records Katter's Australian Party as a party and so his campaign is not considered here. Katter increased his primary and two-party preferred vote share, in part a result of the demise of the Palmer United Party. For more information see Kefford, Chapter 15, this volume. 
represents a regional urban electorate, urban Independent candidates from large metropolitan electorates have been less successful than their regional and rural counterparts. In the 1990s, Ted Mack from North Sydney and Phil Cleary from Wills in Victoria (VIC) won their electorates in Sydney and Melbourne respectively and, in 2016, James Mathison stood in the Sydney seat of Warringah and featured prominently in the Sydney media (see Raue, Chapter 7, this volume). However, it was to be the rural and regional Independents that the national media focused on in 2016.

As such, this chapter provides an overview of the three rural and regional Independents' campaigns (Windsor, Oakeshott and Wilkie) and then offers a closer look at the electorate of Indi (McGowan). ${ }^{2}$ I build on analysis made in Abbott's Gambit: The 2013 Australian Federal Election, where we explored how it was that McGowan was able to win the safe Liberal seat from long-time incumbent, soon-to-be minister, Sophie Mirabella (Curtin and Costar 2014). But the case of Indi also offers us an analytical spotlight on what personality, localism and non-party representation have come to mean, particularly for those in regional Australia. As such, it momentarily shifts the focus away from party choice and towards the phenomenon of candidates attracting support for who they are, or what they have done, or what they might do, rather than simply because of the party to which they belong, or not, in the case of Independents (Bean and Papadakis 1995; Marsh 2007; Weeks 2011).

The explanations for the rise of voter attraction to candidates rather than parties, and Independents in particular, tend to include the personality factor, the impact of the electoral system and the degree of 'localism' (Anckar 2000; Greenberg 1994). Certainly in the case of Australia, the institutional arrangements of compulsory voting combined with preferential voting have come to serve Independents well (Curtin and Costar 2014). And the incremental decline in party identification has been accompanied by a rise of anti-party sentiment that has left some of the established parties dealing with surges of unpopularity in a variety of electorates (Costar and Curtin 2004; Curtin 2004; Rodriques and Brenton 2010). Thus, although it remains unlikely that Independents

2 Interviews and participant observation were conducted by the author in the electorate of Indi two weeks before Turnbull called the election. I am grateful to Ben Raue for directing me to additional information on the Denison how-to-vote information (Australian Labor Party (ALP) 2016). 
will ever replace parties as the main organisational form in parliamentary life, voting for an Independent is no longer deemed by all as irrational behaviour (Bolleyer and Weeks 2009).

\section{Election 2016 and the Independents}

Initially, the national campaign gave little attention to the relevance of the (re)election of Independents to the House of Representatives. All eyes were on the Senate and what the double dissolution, along with the new voting rules, would produce in terms of a result. There appeared to be a general agreement, although muted, that Turnbull would scrape, rather than romp, home; in part because his personal ratings as preferred prime minister sat well above those of Shorten.

Ultimately, however, as we have seen in previous chapters, the result in the lower house was a close-fought race and the Independents once again featured as part of the story. Both major party leaders faced questions on whether they would work with the crossbenchers, and both signed a 'solemn pledge' drafted by the Daily Telegraph undertaking not to form an alliance or do deals with the Greens (Benson 2016). Yet, neither leader ruled out the option of forming a minority government with the support of 'Others' on confidence and supply. This decision proved prescient given the close result, and the re-election of two Independents alongside Katter and the Nick Xenophon Team.

Despite Turnbull's claims that every single vote for the Independents represented a vote for chaos, with predictions of instability and policy paralysis, voters remained undeterred, and four key electorates remained open to wins by Independents. In New South Wales (NSW), Windsor and Oakeshott came out of retirement to contest the electorates of New England and Cowper, while Wilkie and McGowan ran as incumbents in their respective seats of Denison (where the margin was a safe 15 per cent) and Indi (with a margin of just 0.3 per cent). Each of the four campaigns was different, although it was to be Windsor and McGowan who received the most press coverage at the national level, with multipage spreads dedicated to the 'power of one' (Alcorn 2016). Arguably, this was as much about who these Independents were up against as it was about their own individual campaigns. 
Windsor announced his decision to contest his former seat of New England as an Independent candidate in March 2016. This was always likely to be a high-profile battle, given the seat was held by the self-styled larrikin-like National party leader and Deputy Prime Minister Barnaby Joyce (Cockfield and Curtin, Chapter 14, this volume). Joyce had won the seat comfortably upon Windsor's retirement at the 2013 election, but was vulnerable on several policy issues-most visibly the federal government's decision to approve the $\$ 1.2$ billion Shenhua Watermark coalmine in country NSW, which farmers opposed, as well as the national broadband network, the Gonski education reforms (specifically extra funding for country schools), water, renewable energy, anticorruption measures and climate change (Chan 2015, 2016a).

However, the campaign for New England was also personal. The Guardian reported that this was a fight that would test regional voters on policies but 'overlaid are more personal issues such as pride and hubris' (Chan 2016b). Some in the media argued that Joyce wanted to beat Windsor because he had not had the chance to do so in 2013, hinting that there was a lingering resentment from decades past when Windsor left the Nationals to stand as an Independent in the NSW parliament (Costar 2012). Joyce claimed the only reason Windsor was back was to drain resources from the Nationals' broader campaign (see Cockfield and Curtin, Chapter 14, this volume). It worked-Joyce was in the electorate up to three times a week, with the traditional wombat trail curtailed.

Throughout the campaign, Windsor sought to portray himself as an authentic local, compared to Joyce, who was characterised by Windsor as the career politician flown in from Queensland (McKeith 2016). Windsor's platform was more progressive than that of the Nationals (as it had been during his tenure in office), but his message was complicated by his need to defend his family's previous decision to sell land to a mining company. He also battled some personal slurs. National Party advertisements released in the last two weeks of the campaign implied Windsor was a 'philanderer' and he also had to fend off a front-page newspaper story claiming he had been a schoolyard bully (Hunter 2016; SBS 2016).

Personalities aside, Windsor believed that this was the 'first time since I started in politics that I've seen circumstances where the local issues of a country electorate align with the major national issues' (Bettles 2016). He took up these issues with daily posts on Facebook and Twitter 
(his Facebook page and Twitter account both had over 27,000 followers), while also profiling his electorate events, his dog, video clips on how to vote and information on how a hung parliament works in practice. He ran on a strong history of delivering for his electorate as an Independent, and made use of NationBuilder and a good number of volunteers to support a traditional roving ground campaign enabling him to connect with locals across the electorate (Mills 2016; Thomson 2016). Nationally, he was profiled on Four Corners, participated in the Sky News Politics in the Pub program and featured regularly in the national press.

This strategy appeared, on face value, to be working. Prior to Windsor announcing his decision to run, a January ReachTEL poll of 712 residents in the seat had found that 32.2 per cent would vote for Windsor as their first preference if he returned-compared with 39.5 per cent for Joyce (Chan 2016a). Two months later, a poll of 518 voters in the electorate suggested the former Independent member for New England could unseat Joyce, with Windsor ahead 52 points to 48 after preferences (Hudson 2016). That the media considered Windsor an outside chance was reflected in their soliciting of his views on formal agreements should a hung parliament result (Taylor 2016). However, small local polls are considered unreliable at best (see Jackman and Mansillo, Chapter 6, this volume) and, in the end, the Deputy Prime Minister differentiated himself sufficiently from Turnbull to win both core and swing voters.

Similarly to Windsor, Oakeshott's attempt to win in Cowper was always likely to be difficult. Oakeshott had previously represented the electorate of Lyne, from 2008 to 2013 when he retired, but a redistribution had shifted his home town of Port Macquarie into the electorate of Cowper. Oakeshott announced his candidature on 9 June, just three weeks before the election. He stated that he had hoped to see more progress by local MPs on education and health and the disadvantaged communities in his region, but that these issues, along with tax reform and the constitutional recognition of Indigenous peoples, had not been sufficiently addressed since he left parliament. This, he said, drove his decision to re-enter politics (Dziedzic 2016).

However, in part because of his late start date, Oakeshott did not receive the same degree of national media coverage as his Independent colleagues; his campaign was largely limited to local news media, and he had to build his profile from scratch in the major centre of Coffs Harbour. 
Moreover, he was up against long-time sitting National Luke Hartsuyker, first elected in 2001 and well-known in the Coffs Region. Yet, one week out from the election there was a moment of worry that the former Independent might sneak home. It was reported that Coalition strategists had hit the 'panic button', sending the Prime Minister into the electorate to protect Hartsuyker. Considered an unusual move for a PM, Turnbull then followed up by cold-calling a small $\mathrm{ABC}$ radio station to remind voters to vote for the Nationals (Aston 2016). Two weeks earlier, a ReachTEL poll indicated that Hartsuyker's primary vote support had fallen from 53 per cent to 39 per cent, as result of Oakeshott entering the race (ReachTEL 2016). Oakeshott has since claimed the Nationals spent close to $\$ 750,000$ to ensure they would secure the seat, including a $\$ 300,000$ advertising blitz; a mammoth amount compared to his meagre spend of $\$ 52,300$ (Kelly 2016). Ultimately, Oakeshott did better than Windsor in terms of the two-party preferred vote, although this may say more about Joyce's profile and preference deals than the likeability and reputation of the two Independent candidates.

Wilkie was the only Independent almost guaranteed re-election. A locally popular candidate, with a strong primary vote, and a two-party preferred vote of 67.8 per cent in 2013, meant his seat was classified safe. Yet, from the national perspective, his campaign was overshadowed somewhat by the Senate race in Tasmania, and the independently styled Jacqui Lambie in particular. In the lower house, the focus was on whether the sophomore Liberals in three seats with very small margins would be able to hold on. In this sense, Wilkie's campaign was always going to be the least interesting for the media, given it was likely he would face no real contest. Indeed, a ReachTEL poll found 62.4 per cent of Denison voters rated Wilkie highly, making him the best-performing Tasmanian member of federal parliament (Smith 2016).

Wilkie did not take this lead for granted, however, recognising the importance of retaining preferences. He reminded voters that he was the underdog in the seat. Former Labor MP Harry Quick, Deputy Mayor of Glenorchy, had advertised his support for the Liberal candidate in the local paper, suggesting that Labor might direct voters to preference the Liberals (Glenorchy Gazette 2016; Wilkie 2016). Moreover, he had to fend off claims from both the major parties that his capacity to deliver for his electorate was limited because he no longer held the balance of power (Smith 2016). In the end, Wilkie's concerns were unfounded- 
Labor preferenced Wilkie third, after the Greens, and listed the Liberal last, and in the Glenorchy Council area Wilkie narrowly outpolled Labor on primary votes and won around 58 per cent of the two-candidate preferred vote.

While committed to local concerns, such as the redirection of the Cadbury closure spoils to the marginal Liberal electorates instead of the northern suburbs of Hobart located within Denison, Wilkie also continued to champion his signature issues: gambling, animal welfare and the environment (Richards 2016). His views were well represented in the local papers, while nationally, it was his position on government formation that received the most attention. His message was consistent-should another hung parliament result, he would not do deals with any party to form government (Butler 2016; Kelly 2016). Such a focus is perhaps unsurprising. Wilkie was the only sitting Independent who had signed a formal agreement with the Gillard government in 2010. He walked away from the agreement in 2012, relatively unscathed electorally, but this experience enabled him to speak with authority on the realities of minority government in practice. When Turnbull spoke of chaos, Wilkie claimed the PM was being 'blatantly dishonest by trying to claim that power-sharing Parliaments lead to anarchy'. He went on to say:

History shows that in fact power-sharing Parliaments are often quite stable and reformist, as was the case during the 43rd Parliament. It's also extremely arrogant for the Prime Minister to try and tell voters that they shouldn't give their vote to an Independent ... Comments like this are terribly disrespectful of the democratic process which allows every Australian to vote for whichever candidate best reflects their views (Butler 2016).

Both major parties sought to deter voters from choosing Wilkie in particular, and the micro parties and Independents more generally, which was criticised as failing to recognise the value that comes with power sharing (Barns 2016; Dick 2016). This approach also risked raising the ire of voters who were turned off by nationwide negative campaigning at the expense of addressing the grassroots, a point noted by the Nationals in their post-election analysis (Maher 2016). 


\section{A new mode of 'independence' in politics: The case of Indi}

If Wilkie's seat was one of the 'safest' Independent seats in recent memory, McGowan's seat of Indi was one of the most marginal. The story of McGowan winning the seat of Indi from Mirabella in 2013 has been revisited many times. It was spectacular for a number of reasons. Initially portrayed as an anti-Mirabella movement, the contest quickly turned into something more, with McGowan running an issues-based grassroots campaign that harnessed large numbers of volunteers and sufficient resources to ensure a real challenge resulted. Mirabella lost her margin of 9 per cent and lost the seat by only 439 votes. She was the only Liberal MP to lose her seat in a national swing to Tony Abbott. As such, it was always expected that the 2016 campaign would be close.

In late March, an Australia Institute poll found that McGowan had 37.3 per cent of first preference votes, with Mirabella on 26.9 per cent. Support for Mirabella was at its highest in the 65-and-over age group, where two out of five voters would vote for her compared to only 16.4 per cent of 18-24-year-olds. By contrast, McGowan's support was more evenly distributed across age groups, but those in the 51-64 age group responded to her best, with nearly half of voters in this age range saying they would vote for her (Medhora 2016). This result suggested Mirabella would be dependent on preferences flowing from the Nationals candidate, Marty Corboy, whose support was around 10 per cent. However, despite much discussion between the two parties' campaign teams, there was never complete confidence amongst the Liberals that they could count on Nationals supporters giving their preferences to Mirabella over McGowan (Alcorn 2016). Former Nationals leader Warren Truss was clearly a Mirabella supporter, but Joyce was less so, mocking her chances on several occasions and sending mixed messages to voters. Ken Jasper, a Victorian State National MP for four decades, suggested that Nationals voters direct second preferences to McGowan (Chan 2016b; Loussikian 2016).

Understanding McGowan's lead in this early poll requires a review of her time as an MP between 2013 and 2016. As an Independent, who did not hold the balance of power, it could have been difficult to demonstrate she had made a difference. However, rather than focusing solely on winning policy dividends or funding for her electorate (although these 
outcomes remained important), McGowan used her time in office to embed a different kind of representational process, based on two distinct but connected strategies. The first involved taking the 'Voice for Indi' movement to Canberra. McGowan's 2013 campaign was underpinned by a grassroots movement inside Indi that wanted to create change in the way its issues were represented federally. As a candidate, McGowan had engaged in 'kitchen conversations' across the electorate to gather information about local concerns and broader issues such as marriage equality, climate change and asylum seekers. These issues were also discussed and prioritised at an 'Indi Summit'. Not bound by party discipline, McGowan was able to reconcile both conservative and progressive positions articulated across her demographically diverse electorate (Chan 2016c; Curtin and Costar 2014). Once elected, her face-to-face consultation across the electorate grew into an Indi volunteer program whereby Indi constituents volunteered to work as staffers in her parliamentary office (Evans 2014; Hendricks 2016). Hundreds of locals came to experience national politics from the vantage point of an MPs office, the objective being to facilitate a sense of connection and ownership of the political process, and reduce the alienation historically felt by many in safe rural electorates (Curtin 2004).

McGowan's second strategy has come to be known as the 'Indi Way'. Politics, as McGowan describes it, should focus on policy and not the personal, it should be clean and undertaken with integrity, an 'authentic contest of ideas and values' to enable greater knowledge and trust in the democratic process (Alcorn 2016; Evans 2014). The Indi Way informed McGowan's parliamentary voting record: she voted 443 times with the government and 32 times against. The latter included votes in favour of retaining the carbon tax and against the deregulation of university fees, while she supported limited mandatory detention (Morgan 2016). McGowan did not see herself as 'in opposition' but as having a role to work with the government irrespective of who that is to get the best outcome for Indi. She also chose not to align herself with other Independents in the House, although some conversations were inevitable when sharing the crossbench position. And her mode of campaigning was based on building relationships. She is described as having a warm personality and being a good listener, networker and able to work across party lines (Alcorn 2016). This personal dimension was supported with a revised version of the successful campaign strategy employed in 2013. The campaign made innovative use of crowd-funding software, social media strategies, hundreds of volunteers and she had claimed the colour orange as signifier of independence (Evans 2014; Mills 2016). The central office in 
Wangaratta featured posters reminding volunteers of the Indi valuesrespect, inclusivity, positivity, courage, trust, integrity-and McGowan exhibited these qualities during candidate debates (Alcorn 2016).

McGowan's focus on the representational process did not preclude her from working on policy wins for Indi. She claimed that in excess of $\$ 800$ million had been committed to Indi since her election, but that it was a result of collective advocacy. For example, she had worked with the Indi Telecommunications Action Group to draft a whole-ofelectorate plan for federal funding for black spots that resulted in the electorate winning 30 mobile base stations, enough to fix two thirds of the blackspots identified (Alcorn 2016; Morgan 2016). Similarly, she argued that funding for the Wodonga Business District and the awarding of a defence contract to a company in her electorate during her time in office had involved advocacy from herself and others. Both claims were vehemently dismissed by the Liberals for Indi (Smithwick 2015).

Alongside this, the region was experimenting with independence at the State level and experiencing some largesse. Shepparton voters had elected Suzanne Sheed in 2014, and while the Country Fire Authority dispute received considerable attention, the Andrews-led Labor government had committed millions to areas 'where folks have never ever voted for his party' but which was nevertheless welcomed by the Victorian Farmers Federation (Sullivan 2016a, 2016b). This included drought funding, money for the baiting of wild dogs, and \$36 million for rural police, some of which went to stations in McGowan's electorate.

Outside of local politics, McGowan's 'Indi' brand had gained national attention, and stood in stark contrast to Mirabella's brand, with the latter portrayed as abrasive, ambitious, arrogant and 'the Queen of Mean' (Lambert 2016). Mirabella was preselected in June 2015, although her decision to stand was not supported by all in the Victorian Liberal Party and her candidature meant that, as was the case in 2013, the campaign for Indi in 2016 was as much about Mirabella as it was about McGowan. Indeed, those inside the McGowan camp said the latter's campaign strategy may have looked very different without the presence of the polarising Mirabella.

Mirabella did have some influential supporters. The Liberals for Indi campaigned avidly on her behalf and made a loud appearance at the Sky News Politics in the Pub event, while the Australian's attempt to delegimitise 
McGowan's win in 2013 was significant. In 2014, the newspaper claimed 'McGowan's 439-vote winning margin in the Victorian rural seat of Indi came after a number of her dedicated younger backers allegedly engaged in electoral fraud' (Thomas and Arthur 2014). The Liberal Party also put to federal parliament's Joint Standing Committee on Electoral Matters (JSCEM) that fraudulent re-enrolments may have been coordinated in 'a particular seat', which the Australian suggested was Indi (Thomas and Arthur 2014). The Australian identified more than 20 cases where voters had changed addresses shortly before the roll closed and these were then investigated by the Australian Federal Police and the Australian Electoral Commission. It took 18 months for the McGowan campaign to be cleared. Commonwealth prosecutors withdrew electoral fraud charges against two young voters, one of whom was McGowan's niece, four weeks before the 2016 election campaign began. One insider suggested the investigation had involved 27 public servants and 1,850 police hours, while others claimed it to have been a 'shameful political exercise' (Akerman 2016). Meanwhile, local media proclaimed McGowan as 'vindicated', with the electoral fraud claim finally vanquished (Border Mail 2016).

However, it was to be Mirabella's campaign, and the media reporting of it, which damaged the slim chance she had of regaining the seat. First was the 'awkward encounter' at the opening of a new wing of an aged care facility, with the Benalla Ensign reporting that Mirabella 'very publicly pushed Ms McGowan out of the way' to prevent her having a photograph with Liberal MP Ken Wyatt (Savage 2016). Mirabella contested the Ensign's version of events in the press and on Twitter, but the paper did not retract their version for several months. Following this, Mirabella announced live on national television that a $\$ 10$ million allocation for the Wangaratta Hospital did not happen because Indi voters had elected McGowan rather than her in 2013. Treasurer Scott Morrison and Health Minister Sussan Ley stated there had been no public commitment of funds, but accusations of pork-barrelling made headline news for close to a week (Koziol 2016). The Age editorial argued Mirabella's claim offered 'rare and dispiriting insights into dishonourable cynical tactics that political parties adopt in campaigns', which only highlighted the contrast in operating styles of major party and Independent candidates and campaigns (Age 2016: 32). Mirabella's campaign never recovered, and her party support floundered as a result (Gorr 2016). Meanwhile, McGowan was labelled 'Miss Congeniality' and continued to campaign scandal free with largely positive support from local and national media (Kingston 2016). 


\section{The results}

As noted by Ben Raue (Chapter 7, this volume), high-profile Independents ran in five electorates, but only two were elected. Three of the five were contested outside major cities, continuing the tradition of regional Australia's interest in alternatives to major party representation (Costar and Curtin 2004). Nevertheless, despite Windsor's best efforts to challenge Joyce on policy and personality, he won only 29.2 per cent of first preferences compared to Joyce's 52.3 per cent, and Joyce won easily in a majority of booths, both large and small, across the electorate. Windsor held his own in parts of Armidale and Tamworth, but this was not enough to make up for Joyce's wins elsewhere. Similarly, former Independent Oakeshott won just over a quarter of the first preference vote (26.3 per cent) in the NSW seat of Cowper. However, the Nationals incumbent Hartsuyker required preferences to win, in part because of the support Oakeshott received from booths in Port Macquarie, which, prior to the redistribution, had been part of his former electorate of Lyne.

Table 16.1 reveals how close the four rural and regional races (plus Katter's) were in terms of primary and two-party preferred votes. The data indicate it is too soon to yet again suggest that minority governments will become a thing of the past.

Table 16.1. Results for Independents (and Katter), 2013 and 2016

\begin{tabular}{|l|l|l|l|l|l|r|}
\hline Candidate & \multicolumn{2}{|c|}{ Primary vote } & \% change & \multicolumn{2}{c|}{ 2PP } & \% change \\
\hline & 2013 & 2016 & & 2013 & 2016 & \\
\hline $\begin{array}{l}\text { Bob Katter (KAP) } \\
\text { (Kennedy) }\end{array}$ & 29.35 & 39.85 & 10.5 & 52.19 & 61.12 & 8.93 \\
\hline Rob Oakeshott (Cowper) & & 26.29 & & & 45.44 & \\
\hline $\begin{array}{l}\text { Tony Windsor } \\
\text { (New England) }\end{array}$ & 29.22 & & & 41.48 & \\
\hline Andrew Wilkie (Denison) & 38.08 & 44.07 & 5.99 & 65.51 & 67.78 & 2.27 \\
\hline Cathy McGowan (Indi) & 31.18 & 34.76 & 3.58 & 50.25 & 54.83 & 3.58 \\
\hline
\end{tabular}

Source. Compiled by author from Australian Electoral Commission (n.d.). 
Ultimately, it was to be the two incumbent Independents who won, and won well. Wilkie achieved 44 per cent of the primary vote in Denison, an increase of 6 per cent and 21 per cent ahead of Labor's candidate. Wilkie went on to win 67.8 per cent of the two-party preferred vote, and preference flows reveal Wilkie's appeal is politically broad-he received 72 per cent of Green preferences and 75 per cent of Liberal preferencesmaking Denison an incredibly safe seat for an Independent.

McGowan's race was more complex. She was subject to a threecornered contest meaning the Liberals and Nationals were likely to be exchanging preferences with potentially damaging consequences. In the end, McGowan received 85 per cent of Green preferences, 84 per cent from Labor and 27 per cent from the Nationals, and her appeal was geographically wideranging; she outpolled her opposition in three quarters of the booths, and was the clear winner in both Wodonga and Wangaratta. In some smaller towns and in a couple of the Wangaratta booths, the Nationals candidate came in ahead of Mirabella. The total first preference vote for the Coalition parties totalled 44 per cent and the seat remains marginal, with McGowan winning 54.8 per cent two-party preferred, up 3.6 per cent from 2013.

\section{Conclusions}

It has been argued that the success of Independents is best measured using the framework of 'policy, office, or votes', with involvement in government formation being a significant feat (Miller and Curtin 2011). However, the outcome of the 2016 election for the Independents, and their decision to support confidence and supply only, suggests that Australian Independents have a more measured view of success. Instead of deals, they have chosen to retain their independence, looking to work with government, issue by issue, in a way that is responsible, ensures government stability, but protects their capacity to represent both local and regional concerns.

In the case of McGowan, she has taken what it means to be a local representative to a new level, building connections and a level of engagement with Canberra that has democratic potential but is only possible in the absence of a party machine. The McGowan model is not unlike the representational style of Andren in that it involves championing reforms to the democratic process, taking a progressive stand on moral and human rights issues, while also working on local issues (Costar and 
Curtin 2004). Comparatively, the former is less common, as there is often a tendency for Independents to focus solely on local parochialism and protest votes in ways that are conceived of as populist or reactionary (Brancatti 2008; Hijino 2013). However, the type of Independent elected in Australia has been sufficiently varied over time to suggest that there is no one 'model' of independent representation. In rural Australia at least, it seems the election of Independents has helped to revive and reinvigorate the Nationals campaign style and their electoral fortunes. The presence of Windsor and Oakeshott reminded the Coalition's partner of the need to focus on the grassroots and local communities, and to be prepared to address both progressive and traditional issues. In the case of Indi, there is a hint that the seat is being 'set up' for a return to the Nationals in 2019, complementing their win in the adjacent seat of Murray (Grattan 2016). More generally, however, there is continuing evidence that rural and regional voters are open to supporting candidates unconnected to the major parties on the right. The shifts identified in this election may not be sufficiently seismic to disrupt Australia's two-and-a-half party system, but it should be a warning to political leaders that dismissing a vote for 'Others' as potentially chaotic offers few deterrent effects.

\section{References}

Age. 2016. 'Mirabella’s grubby deal is unacceptable'. Age, 23 April, p. 32.

Akerman, Pia. 2016. 'Indi electoral fraud charges against Cathy McGowan's niece dropped'. Australian, 5 April. Available at: www. theaustralian.com.au/business/legal-affairs/indi-electoral-fraudcharges-against-cathy-mcgowans-niece-dropped/news-story/ad3d 6d757d98e6cb65a36136ebf55e6e

Alcorn, Gay. 2016. 'Will Indi hold on to the power of one?' Guardian, 27 May. Available at: www.theguardian.com/australia-news/2016/ may/28/election-2016-cathy-mcgowan-sophie-mirabella-will-indihold-on-to-the-power-of-one

Anckar, Dag. 2000. 'Party systems and voter alignments in small island states'. In Lauri Karvonen and Stein Kuhnl (eds), Party Systems and Voter Alignments Revisited. London: Routledge, pp. 261-83. doi. org/10.4324/9780203469323_chapter_13 
Aston, Heath. 2016. 'Federal election 2016: Coalition panics at possible return of Rob Oakeshott in seat of Cowper, deploys Malcolm Turnbull'. Sydney Morning Herald, 28 June. Available at: www.smh. com.au/federal-politics/federal-election-2016/federal-election-2016coalition-panics-at-possible-return-of-rob-oakeshott-in-seat-ofcowper-deploys-malcolm-turnbull-20160628-gptjdh.html

Australian Electoral Commission (AEC). n.d. 'Official Election Results'. Tally Room Archive. Available at: results.aec.gov.au

Australian Labor Party (ALP). 2016. 'How to vote for Bill Shorten and Labor in New South Wales'. Available at: alp-assets.s3.amazonaws. com/documents/ALP_National_HTV_2016.pdf

Barns, Greg. 2016. 'Major parties fall short on critical policies'. The Mercury, 20 June. Available at: www.themercury.com.au/news/ opinion/talking-point-major-parties-fall-short-on-critical-policies/ news-story/a5e529f9812361ce168a3249b77def4d

Bean, Clive and Elim Papadakis. 1995. 'Minor parties and independents: Electoral bases and future prospects'. Australian Journal of Political Science 30(1): 111-26.

Benson, Simon. 2016. 'Federal election 2016: Turnbull, Shorten pledge to never repeat Gillard/Greens experiment'. Daily Telegraph, 11 May. Available at: www.dailytelegraph.com.au/news/nsw/federalelection-2016-turnbull-shorten-pledge-to-never-repeat-gillardgreensexperiment/news-story/c62ed14911e5c4b4933934586416adb6

Bettles, Colin. 2016. 'Windsor claims underdog against Joyce'. The Land, 10 March. Available at: www.theland.com.au/story/3784453/windsorclaims-underdog-against-joyce/

Black, John. 2016. 'Federal election 2016: Arm yourself for an educated, lubricated sit-in'. Australian, 2 July. Available at: www.theaustralian. com.au/opinion/columnists/john-black/federal-election-2016-armyourself-for-an-educated-lubricated-sitin/news-story/82a6779b9845 8c16c7f98c4936a8924b

Bolleyer, Nicole and Liam Weeks. 2009. 'The puzzle of non-party actors in party democracy: Independents in Ireland'. Comparative European Politics 7(3): 299-324. doi.org/10.1057/cep.2008.21 
Border Mail. 2016. 'Politics in pub represents an Indi litmus test'. Border Mail, 20 April, p. 15.

Brancatti, Dawn. 2008. 'Winning alone: The electoral fate of independent candidates worldwide'. The Journal of Politics 70(3): 648-62. doi.org/ $10.1017 /$ S0022381608080675

Butler, Josh. 2016. 'Why Malcolm Turnbull is so scared of people voting independents'. Huffington Post, 27 June. Available at: www. huffingtonpost.com.au/2016/06/26/why-malcolm-turnbull-is-soscared-of-people-voting-independents/

Chan, Gabrielle. 2015. 'Nationals elect party president with ties to Shenhua mining company'. Guardian, 13 September. Available at: www.theguardian.com/australia-news/2015/sep/13/nationals-electparty-president-with-ties-to-shenhua-mining-company

__ 2016a. 'Tony Windsor could beat Barnaby Joyce in New England seat, poll says'. Guardian, 28 February. Available at: www.theguardian. com/australia-news/2016/feb/29/tony-windsor-could-beat-barnabyjoyce-in-new-england-seat-poll-says

_-2016b. 'Rural Australia at a political crossroads as ties of conservative loyalty fray'. Guardian, 5 June. Available at: www.theguardian.com/ australia-news/2016/jun/05/rural-australia-political-crossroads-oldties-loyalty-fray

__. 2016c. 'Marriage equality, asylum seekers, renewables: McGowan launches Indi campaign'. Guardian, 5 June. Available at: www. theguardian.com/australia-news/2016/jun/06/election-2016-marriageequality-asylum-seekers-renewables-cathy-mcgowan-launches-indicampaign

Costar, Brian. 2012. 'Seventeen days to power: Making a minority government'. In Marian Simms and John Wanna (eds), Julia 2010: The Caretaker Election. Canberra: ANU E Press, pp. 357-70. Available at: press-files.anu.edu.au/downloads/press/p169031/pdf/ch28.pdf

Costar, Brian and Jennifer Curtin. 2004. Rebels with a Cause. Independents in Australian Politics. Sydney: UNSW Press. 
Curtin, Jennifer. 2004. The Voice and the Vote of the Bush: The Representation of Rural and Regional Australia in the Federal Parliament. Canberra: Department of Parliamentary Services and the Parliamentary Library.

Curtin, Jennifer and Brian Costar. 2014. 'The Contest for Rural Representation: The celebrated contest over Indi and the fate of the independents'. In Carol Johnson and John Wanna with Hsu-Ann Lee (eds), Abbott's Gambit: The 2013 Australian Federal Election. Canberra: ANU Press, pp. 275-91. doi.org/10.22459/AG.01.2015.16

Davey, Melissa. 2016. 'Election 2016: Turnbull urges voters to avoid "chaos of a hung parliament". Guardian, 4 June. Available at: www. theguardian.com/australia-news/2016/jun/04/election-2016-turnbullurges-voters-to-avoid-chaos-of-a-hung-parliament

Dick, Tim. 2016. 'Sophie Mirabella: Pork barrelling on its way to Indi'. Sydney Morning Herald, 24 April. Available at: www.smh.com.au/ comment/sophie-mirabella-a-case-for-proportional-representation20160424-godp9x.html

Dziedzic, Stephen. 2016. 'Election 2016: Former independent MP Rob Oakeshott announces candidacy for seat of Cowper'. $A B C$ News, 10 June. Available at: www.abc.net.au/news/2016-06-10/roboakeshott-to-contest-election/7499970

Evans, Brett. 2014. 'The insurgent from Indi'. Inside Story, 30 April. Available at: insidestory.org.au/the-insurgent-from-indi

Glenorchy Gazette. 2016. 'Advertisement'. Glenorchy Gazette, June. Available at: www.glenorchygazette.com.au/wp-content/ uploads/2016/06/GG-JUNE-2016-WEB.pdf

Gorr, Libbi. 2016. 'Election 2016: Sophie Mirabella suspects Liberal HQ leaking against her in fight for Indi'. ABC News, 16 May. Available at: www.abc.net.au/news/2016-05-16/mirabella-suspects-liberal-hq-ofleaking-against-her/7419034

Grattan, Michelle. 2016. 'Campaigning in Indi, Warren Truss was the country boy at the B\&S ball avoiding Sophie Mirabella's toes'. The Conversation, 19 January. Available at: theconversation.com/ campaigning-in-indi-warren-truss-was-the-country-boy-at-the-bandsball-avoiding-sophie-mirabellas-toes- 53392 
Greenberg, Stanley B. 1994. Third Force: Why Independents Turned against Democrats - and How to Win Them Back. Washington: Democratic Leadership Council.

Hendricks, Carolyn. 2016. 'Who says democracy is dead?' Asia and the Pacific Policy Society, 5 December. Available at: www.policyforum.net/ says-democracy-dead/

Hijino, Ken Victor L. 2013. 'Liabilities of partisan labels: Independents in Japanese local elections'. Social Science Japan Journal 16(1): 63-85. doi.org/10.1093/ssjj/jys024

Hudson, Phillip. 2016. 'Newspoll: One in four voters may spurn voting for major parties'. Australian, 6 June. Available at: www.theaustralian. com.au/federal-election-2016/newspoll-one-in-four-voters-mayspurn-voting-for-major-parties/news-story/eda17567d65d613ffc36c $77 \mathrm{~d} 63767 \mathrm{f} 1 \mathrm{~b}$

Hunter, Fergus. 2016. "Bully" accusations - Windsor won't "dignify" story'. Northern Daily Leader, 28 June. Available at: www.northern dailyleader.com.au/story/3998345/bully-accusations-windsor-wontdignify-story/

Hutchens, Gareth. 2016. 'Cathy McGowan offers to support Coalition after meeting with Malcolm Turnbull'. Guardian, 8 July. Available at: www.theguardian.com/australia-news/2016/jul/08/cathy-mcgowanoffers-to-support-coalition-after-meeting-with-malcolm-turnbull

Ipsos. 2016. 'Labor retains narrow lead'. 17 June. Available at: ipsos.com. au/fairfax/labor-retains-narrow-lead/

Kelly, Joe. 2016. 'Federal election 2016: Rob Oakeshott banks cash "for next tilt". Australian, 7 July. Available at: www.theaustralian.com.au/ federal-election-2016/federal-election-2016-rob-oakeshott--bankscash-for-next-tilt/news-story/b78e086c44a3b1476c22dfce26548ef5

Kimmorley, Sarah. 2016. 'Tasmanian independent MP Andrew Wilkie backs Turnbull'. Business Insider, 8 July. Available at: www.business insider.com.au/tasmanian-independent-mp-andrew-wilkie-backsturnbull-2016-7 
Kingston, Margo. 2016. 'Queen of Mean takes on Miss Congeniality and \#Indivotes braces for the onslaught: @Jansant reports'. No Fibs, 11 May. Available at: nofibs.com.au/queen-of-mean-takes-on-misscongeniality-and-indivotes-braces-for-the-onslaught-jansant-reports/

Koziol, Michael. 2016. 'Turnbull government ministers duck for cover after Sophie Mirabella comments embarrass the Coalition'. Sydney Morning Herald, 23 April. Available at: www.smh.com.au/federalpolitics/federal-election-2016/turnbull-government-ministers-duckfor-cover-after-sophie-mirabella-comments-embarrass-the-coalition20160422-gocy79.html

Lambert, Olivia. 2016. 'The rise and fall of the "Queen of Mean"'. news. com.au, 17 May. Available at: www.news.com.au/national/federalelection/the-rise-and-fall-of-the-queen-of-mean/news-story/9a30e98 8e288f5b022de1eee93576629

Loussikian, Kylar. 2016. 'Federal election 2016: Libs' fury at Kelly's role in Lindsay loss'. Australian, 5 July. Available at: www.theaustralian. com.au/federal-election-2016/federal-election-2016-libs-fury-atkellys-role-in-lindsay-loss/news-story/ef926805293b2f4ae1866662 726b86b6

Maher, Sid. 2016. 'Federal election 2016: Nationals savage "aloof" Liberals'. Australian, 6 July. Available at: www.theaustralian.com.au/ federal-election-2016/federal-election-2016-nationals-savage-aloofliberals/news-story/c217c4c4de34171445db0e66b0dfde0f

Marsh, Michael. 2007. 'Candidates or parties? Objects of electoral choice'. Party Politics 13(4): 500-27. doi.org/10.1177/1354068807075944

McKeith, Sam. 2016. "I have lived here all of my life": Windsor steps up New England fight'. Huffington Post, 4 June. Available at: www.huffingtonpost.com.au/2016/06/03/i-have-lived-here-all-ofmy-life-windsor-steps-up-new-england/

Medhora, Shalailah. 2016. 'Cathy McGowan says poll shows she could lose seat to Sophie Mirabella'. Guardian, 30 March. Available at: www. theguardian.com/australia-news/2016/mar/30/cathy-mcgowan-sayspoll-shows-she-could-lose-seat-to-sophie-mirabella 
Miller, Raymond and Jennifer Curtin. 2011. 'Counting the costs of Coalition: The case of New Zealand'. Political Science 63(1): 106-25. doi.org/10.1177/0032318711407294

Mills, Stephen. 2016. 'How Australian activists used Obama-style micro targeting in the 2016 election'. Democratic Audit UK, 4 October. Available at: www.democraticaudit.com/2016/10/04/how-australianactivists-used-obama-style-micro-targeting-in-the-2016-elections/

Morgan, Shana. 2016. 'Indi votes: Cathy McGowan says winning margin to grow'. Border Mail, 5 June. Available at: www.bordermail.com.au/ story/3949656/margin-to-grow-cathy/

ReachTEL. 2016. '7 News Cowper Poll'. ReachTEL Blog, 23 June. Available at: www.reachtel.com.au/blog/7-news-cowper-poll-23june2016

Richards, Blair. 2016. 'Liberal seats win the choccies as Andrew Wilkie says Cadbury cash splash "betrays" northern suburbs'. Mercury, 13 May. Available at: www.news.com.au/national/tasmania/liberalseats-win-the-choccies-as-andrew-wilkie-says-cadbury-cash-splashbetrays-northern-suburbs/news-story/721abea4511df8c5329ea7c866 $7 \mathrm{fc} 005$

Rodriques, Mark and Scott Brenton. 2010. 'The age of independence? Independents in Australian parliaments'. Research Paper No. 4. 2010-11, 21 September. Canberra: Parliamentary Library.

Savage, Alison. 2016. 'Sophie Mirabella, former Liberal MP, denies pushing opponent Cathy McGowan at function'. $A B C$ News, 21 April. Available at: www.abc.net.au/news/2016-04-21/sophiemirabella-former-liberal-mp-denies-pushing-opponent/7346262

Smith, Matt. 2016. 'Independent MP Andrew Wilkie hard to roll in diverse Denison'. Mercury, 29 May. Available at: www.themercury. com.au/news/politics/independent-mp-andrew-wilkie-hard-to-rollin-diverse-denison/news-story/465f970f2a2e6deb23e9c4623b40 $7 \mathrm{~b} 53$

Smithwick, Matthew. 2015. 'Member for Indi Cathy McGowan won't comment on battle for seat'. Border Mail, 16 May. Available at: www. bordermail.com.au/story/3082945/its-cagey-member-for-indi-cathymcgowan-wont-comment-on-battle-for-seat/ 
Special Broadcasting Service (SBS). 2016. 'Tony Windsor demands apology for "gutter" attack ad that left his wife "deeply upset". SBS News, 27 June. Available at: www.sbs.com.au/news/article/2016/06/27/tonywindsor-demands-apology-gutter-attack-ad-left-his-wife-deeply-upset

Sullivan, Kath. 2016a. 'Rural policy get $\$ 36 \mathrm{~m}$ lift'. Weekly Times, 20 April, p. 12.

- 2016b. 'Labor largesse is an odd fit in Nationals patch'. Weekly Times, 20 April, p. 20.

Taylor, Lenore. 2016. 'Deal and no deal: Decoding Turnbull and Shorten's double talk on minority rule'. Guardian, 30 May. Available at: www.theguardian.com/australia-news/2016/may/30/ election-2016-deal-and-no-deal-decoding-turnbull-and-shortensdouble-talk-on-minority-rule

Thomas, Hedley and Becky Arthur. 2014. "Batch of "false" votes tars Cathy McGowan's Indi win'. Australian, 27 September. Available at: www.theaustralian.com.au/national-affairs/batch-of-false-votes-tarscathy-mcgowans-indi-win/news-story/5d4128b4a1f80e109062dd8fd d3f634c

Thomson, Craig. 2016. 'Tony thanks volunteers'. Glen Innes Examiner, 25 July. Available at: www.gleninnesexaminer.com.au/story/4051491/ tony-windsor-thanks-glen-innes-volunteers-for-their-support/

Weeks, Liam. 2011. "'Rage against the machine”: Who is the independent voter?' Irish Political Studies 26(1): 19-43. doi.org/10.1080/0790718 4.2011 .531104

Wilkie, Andrew. 2016. 'Labor set to preference Liberals in Denison again'. Available at: andrewwilkie.org/project/labor-set-to-preferenceliberals-in-denison-again/ 
This text is taken from Double Disillusion: The 2016 Australian Federal Election, edited by Anika Gauja, Peter Chen, Jennifer Curtin and Juliet Pietsch, published 2018 by ANU Press, The Australian

National University, Canberra, Australia.

doi.org/10.22459/DD.04.2018.16 